\title{
Temperature and predator-mediated regulation of plasma cortisol and brain gene expression in juvenile brown trout (Salmo trutta)
}

\author{
Karl Filipsson * ${ }^{*}$, Eva Bergman, Larry Greenberg, Martin Österling, Johan Watz and Ann Erlandsson
}

\begin{abstract}
Background: Temperature affects many aspects of performance in poikilotherms, including how prey respond when encountering predators. Studies of anti-predator responses in fish mainly have focused on behaviour, whereas physiological responses regulated through the hypothalamic-pituitary-interrenal axis have received little attention. We examined plasma cortisol and mRNA levels of stress-related genes in juvenile brown trout (Salmo trutta) at 3 and $8{ }^{\circ} \mathrm{C}$ in the presence and absence of a piscivorous fish (burbot, Lota lota).

Results: A redundancy analysis revealed that both water temperature and the presence of the predator explained a significant amount of the observed variation in cortisol and mRNA levels (11.4 and 2.8\%, respectively). Trout had higher cortisol levels in the presence than in the absence of the predator. Analyses of individual gene expressions revealed that trout had significantly higher mRNA levels for 11 of the 16 examined genes at 3 than at $8{ }^{\circ} \mathrm{C}$, and for one gene (retinol-binding protein 1), mRNA levels were higher in the presence than in the absence of the predator. Moreover, we found interaction effects between temperature and predator presence for two genes that code for serotonin and glucocorticoid receptors.

Conclusions: Our results suggest that piscivorous fish elicit primary stress responses in juvenile salmonids and that some of these responses may be temperature dependent. In addition, this study emphasizes the strong temperature dependence of primary stress responses in poikilotherms, with possible implications for a warming climate.
\end{abstract}

Keywords: Anti-predator, Burbot, Climate change, HPI axis, mRNA, Salmonid, Stress, Winter

\section{Background}

Outcomes of predator-prey interactions depend on the relative performance of predator and prey, which can be strongly temperature dependent in poikilotherms [1-4]. Therefore, temperature is predicted to have strong effects on anti-predator responses [1, 3-5]. Prey fishes, such as juvenile salmonids, typically respond to the presence of piscivorous fish [6-12] and the strength of these

\footnotetext{
* Correspondence: karl.filipsson@kau.se

River Ecology and Management, Department of Environmental and Life

Sciences, Karlstad University, Universitetsgatan 2, SE-651 88 Karlstad, Sweden
}

responses may change with water temperature [13-17]. Temperature effects on anti-predator responses in fish have mainly been studied in tropical and warmtemperate systems and rarely under winter conditions [12]. Although temperatures all over the Earth are increasing as a result of climate change, global warming is pronounced in boreal and Arctic regions, especially during the winter season [18-23]. Hence, elevated winter temperatures can possibly have major effects on antipredator responses of fishes.

C C The Author(s). 2020 Open Access This article is licensed under a Creative Commons Attribution 4.0 International License, which permits use, sharing, adaptation, distribution and reproduction in any medium or format, as long as you give appropriate credit to the original author(s) and the source, provide a link to the Creative Commons licence, and indicate if changes were made. The images or other third party material in this article are included in the article's Creative Commons licence, unless indicated otherwise in a credit line to the material. If material is not included in the article's Creative Commons licence and your intended use is not permitted by statutory regulation or exceeds the permitted use, you will need to obtain permission directly from the copyright holder. To view a copy of this licence, visit http://creativecommons.org/licenses/by/4.0/ The Creative Commons Public Domain Dedication waiver (http://creativecommons.org/publicdomain/zero/1.0/) applies to the data made available in this article, unless otherwise stated in a credit line to the data. 
Physiological stress is an adaptive response that allows animals to react to disturbance, such as predation threat $[24,25]$. Primary stress responses include neuroendocrine regulation through the hypothalamic-pituitaryinterrenal (HPI) axis [24, 26], through which corticotropin releasing factor (CRF) induces the release of cortisol into the circulatory system [26, 27]. Cortisol acts through glucocorticoid receptors (GR) and mineralocorticoid receptors (MR) [24], which are involved in modulation of the stress response and results in behavioural changes [28-30]. Cortisol levels generally increase in fish in the presence of predators [31-35], and fish from areas with high and low predation pressure can exhibit differences in both cortisol regulation and behaviour [36, 37]. The serotonergic (5-HT) system is also associated with the HPI axis. Increased serotonergic activity is involved in stress responses in teleosts [38-40] and has subsequent effects on behaviour [38, 39, 41, 42]. Changes in serotonergic activity have been observed in fish in the presence of predators $[43,44]$. Cortisol and serotonin levels in fish can also increase as a response to thermal stress [24, 45-47]. In addition, arginine-vasotocin (AVT) regulation occurs through the HPI axis [48] and is strongly associated with social and aggressive behaviours in teleosts [49-52].

Secondary stress responses include effects on metabolism and immune function $[24,27,53]$. Immune responses are activated when stressors are short-term and acute, whereas chronic stressors result in suppressed immune function [53, 54]. Expressions of genes associated with immune function, such as calmodulin (CALM), gamma-aminobutyric acid receptor-associated protein (GABARAP), major histocompatibility complex I (MHC1) and retinol binding protein (RPB1), may therefore be affected by external stressors. Regulation of ependymin (EPD1), the most abundant glycoprotein in fish cerebrospinal fluid [55], is affected by environmental stress and involved in cold acclimation [56, 57]. CALM, EPD1, GABARAP and RBP1 are also involved in neural and behavioural plasticity $[30,55,58,59]$, and previous work shows that regulation of all the above mentioned genes are involved in stress responses in salmonids [60, 61]. For example, rainbow trout (Oncorhynchus mykiss) have higher mRNA levels of EPD1, GABARAP and CRF after a simulated attack from an avian predator [62]. Gene expressions of antioxidative stress proteins such as glutathione reductase (GSR), although not regulated through the HPI axis, may also be affected by environmental stressors, which has been shown in brown trout (Salmo trutta) exposed to heavy metals [63].

Whole-animal responses to physiological stress, such as behaviour and growth, are often termed tertiary responses [64, 65]. Secondary and tertiary stress responses in the presence of predators are well studied in salmonids $[11,12,66-68]$, whereas primary responses, i.e. gene expression and endocrine regulation, have not received as much attention (but see [31, 62, 69]). To understand the mechanisms underlying anti-predator behaviours in fish, studies of primary physiological stress responses and their associated gene expressions could provide valuable insight into the direct effects of environmental stressors. Hence, studies of genes associated with stress such as CRF, as well as cortisol, 5-HT and AVT receptor genes, may elucidate how fish respond to changes in water temperature and natural stressors such as predation risk.

The purpose of this study was to examine physiological stress responses in a juvenile salmonid at different winter temperatures in the presence and absence of a predator. Specifically, we examined plasma cortisol levels and brain gene expression (measured as relative mRNA levels) for stress-related genes in juvenile brown trout at 3 and at $8{ }^{\circ} \mathrm{C}$ in the presence and absence of burbot (Lota lota), a winter-active piscivorous fish. We predicted that trout would exhibit increased cortisol levels in the presence of burbot, thus indicating physiological stress. Likewise, we predicted that telencephalic gene expressions would be higher in the presence of burbot than in its absence, and that the expressions might be temperature dependent.

\section{Results}

\section{Multivariate analysis}

The first axis of the redundancy analysis (RDA) was driven by the temperature treatment, which explained a significant amount of the observed variation in cortisol and mRNA levels (11.4\% of all variation, $F_{1,69}=9.7, P=$ 0.002). Predator treatment explained the variation on the second axis. The presence or absence of a burbot explained less variation than the temperature treatment, albeit a significant amount $\left(2.8 \%\right.$ of all variation, $F_{1,69}=$ 2.8, $P=0.03$ ) (Fig. 1).

\section{Cortisol}

There was a significant effect of predator presence on trout plasma cortisol levels (Table 1). Trout had higher cortisol levels (mean \pm 1 s.e.) in the presence of the predator $\left(82.6 \pm 15.9 \mathrm{ng} \mathrm{ml}^{-1}\right)$ than in its absence $(45.7 \pm$ $7.6 \mathrm{ng} \mathrm{ml}^{-1}$ ) (Fig. 2). Temperature and the temperature $\times$ predator interaction had no significant effect on cortisol levels (Table 1).

\section{Telencephalic gene expression}

Temperature had a significant effect on mRNA levels of 5-HT1A $\alpha$, CRFR1, CRHBP, EPD1, GABARAP, GR $\alpha$, GR $\beta$, GSR, MHC1 and MR (Table 1). All these genes exhibited the same expression pattern: trout had higher mRNA levels at 3 than at $8^{\circ} \mathrm{C}$ (Fig. 3). There was no significant 


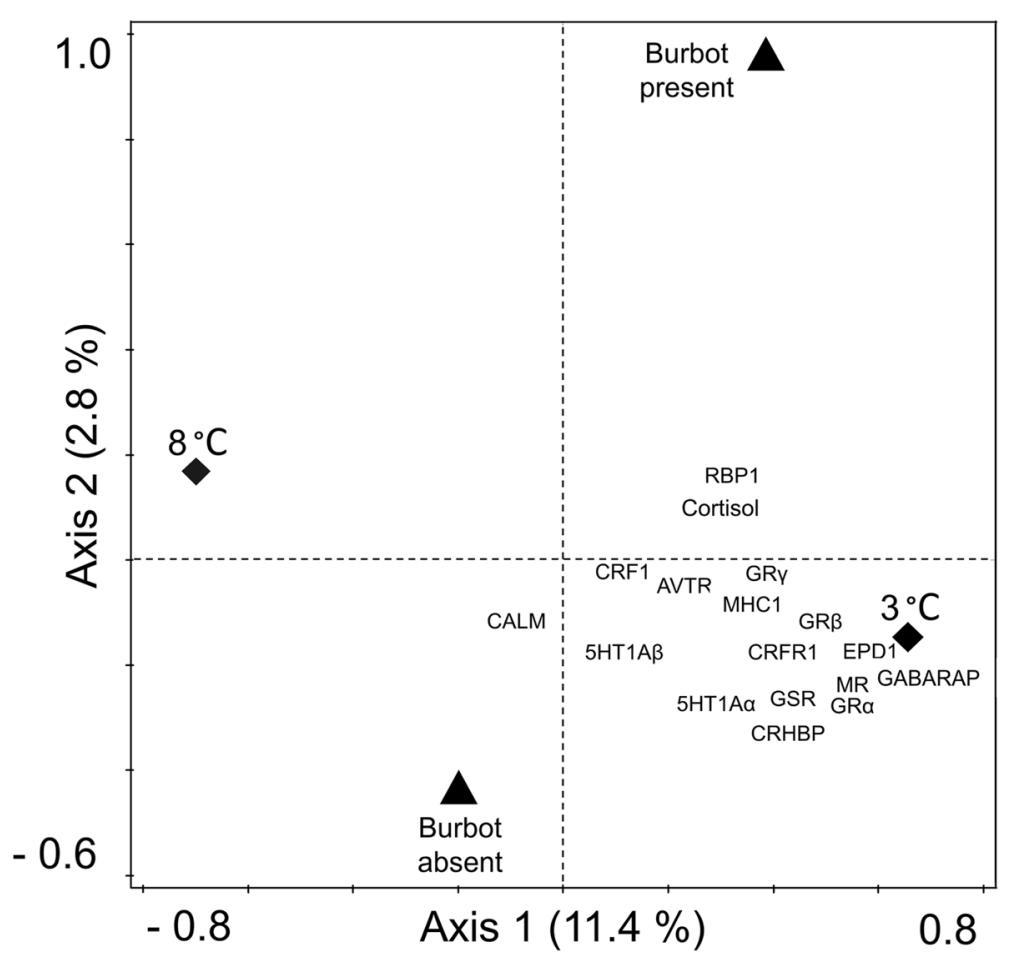

Fig. 1 Ordination plot of the redundancy analysis (RDA). The RDA was constructed using gene expression (mRNA levels) and cortisol data from juvenile brown trout (Salmo trutta) ( $N=79$, see Table 3) subjected to two experimental treatments (water temperature and presence/absence of predatory burbot (Lota lota)). The two temperatures $\left(3\right.$ and $\left.8{ }^{\circ} \mathrm{C}\right)$ drive the variation on axis one and explain $11.4 \%$ of the total variation in the data. Axis two is driven by burbot presence/absence and explains $2.8 \%$ of the total variation. The position of each response variable in relation to the intersection of the two orthogonal axes indicates the direction of the positive correlation, whereas the distance between intersect and each variable describes the strength of the effect. Biplot arrows have been removed for clarity

effect of the predator or of the temperature $\times$ predator interaction term for any of these genes (Table 1).

There was no significant effect of temperature (albeit marginally non-significant, Table 1 ) or predator presence for 5 -HT1A $\beta$, but there was a statistically significant temperature $\times$ predator interaction effect (Table 1). 5HT1A $\beta$ mRNA levels were significantly lower in the $8{ }^{\circ} \mathrm{C} /$ burbot treatment compared to in the other three experimental treatments (Fig. 4a). For the expression of GR $\gamma$, we found no effect of the predator, but both significant temperature and temperature $\times$ predator interaction effects (Table 1 ). At $3^{\circ} \mathrm{C}$, the expression of GR $\gamma$ mRNA was higher in the presence than in the absence of the predator. At $8^{\circ} \mathrm{C}$, however, the expression pattern was reversed (Fig. 4b).

We found a significant positive effect of predator presence on the expression of RBP1 (Table 1, Fig. 4c). Temperature and the temperature $\times$ predator interaction term had no significant effect on RBP1 mRNA expression (Table 1). We did not find any significant effects of temperature, predator presence or their interaction term on mRNA levels of AVTR, CALM and CRF1 (Table 1).

\section{Discussion}

Anti-predator behaviours in the presence of piscivorous fish have previously been observed in juvenile brown trout under winter conditions $[11,12]$. In the present study, we investigated whether or not anti-predator behaviours are accompanied by changes in plasma cortisol and mRNA levels of stress-related genes. We found elevated plasma cortisol levels in the presence of burbot. In addition, our study demonstrated that for 11 of the analysed 16 genes, trout had higher mRNA levels at 3 than at $8{ }^{\circ} \mathrm{C}$, and that mRNA levels for one gene coding for retinol binding protein 1 was significantly higher in the presence of burbot. Moreover, there were interaction effects between temperature and predator presence for the expressions of one glucocorticoid and one serotonin receptor gene. Hence, we show that anti-predator behaviours appear to be reflected by altered cortisol levels and brain mRNA coding for proteins involved in physiological stress responses.

Considering the observed differences in mRNA levels between temperature treatments, these responses are not likely related to thermal stress, but may simply 
Table 1 Statistical outputs from two-way ANOVAs, showing the effects of temperature, the presence of predatory burbot and their interaction term on plasma cortisol levels and telencephalic mRNA levels in juvenile brown trout. Text written in bold denotes statistically significant differences

\begin{tabular}{|c|c|c|c|}
\hline & Temperature & Predator (burbot) & Temperature $\times$ Predator \\
\hline Cortisol & $\begin{array}{l}F_{1,76}=3.11 \\
P=0.08\end{array}$ & $\begin{array}{l}F_{1,76}=7.22 \\
P=0.009\end{array}$ & $\begin{array}{l}F_{1,76}=0.02 \\
P=0.88\end{array}$ \\
\hline 5-HT1Aa & $\begin{array}{l}F_{1,75}=13.63 \\
P<0.001\end{array}$ & $\begin{array}{l}F_{1,75}=1.80 \\
P=0.18\end{array}$ & $\begin{array}{l}F_{1,75}=0.03 \\
P=0.87\end{array}$ \\
\hline $5-H T 1 A \beta$ & $\begin{array}{l}F_{1,75}=3.83 \\
P=0.054\end{array}$ & $\begin{array}{l}F_{1,75}=2.66 \\
P=0.11\end{array}$ & $\begin{array}{l}F_{1,75}=4.67 \\
P=0.034\end{array}$ \\
\hline AVTR & $\begin{array}{l}F_{1,75}=2.67 \\
P=0.11\end{array}$ & $\begin{array}{l}F_{1,75}=0.10 \\
P=0.75\end{array}$ & $\begin{array}{l}F_{1,75}=0.81 \\
P=0.37\end{array}$ \\
\hline CALM & $\begin{array}{l}F_{1,75}=0.70 \\
P=0.41\end{array}$ & $\begin{array}{l}F_{1,75}=1.52 \\
P=0.22\end{array}$ & $\begin{array}{l}F_{1,75}=0.21 \\
P=0.65\end{array}$ \\
\hline CRF1 & $\begin{array}{l}F_{1,75}=0.01 \\
P=0.92\end{array}$ & $\begin{array}{l}F_{1,75}=0.25 \\
P=0.62\end{array}$ & $\begin{array}{l}F_{1,75}=2.14 \\
P=0.15\end{array}$ \\
\hline CRFR1 & $\begin{array}{l}F_{1,75}=13.22 \\
P=0.001\end{array}$ & $\begin{array}{l}F_{1,75}=0.31 \\
P=0.58\end{array}$ & $\begin{array}{l}F_{1,75}=1.77 \\
P=0.19\end{array}$ \\
\hline CRHBP & $\begin{array}{l}F_{1,75}=12.78 \\
P=0.001\end{array}$ & $\begin{array}{l}F_{1,75}=1.18 \\
P=0.28\end{array}$ & $\begin{array}{l}F_{1,75}=0.39 \\
P=0.54\end{array}$ \\
\hline EPD1 & $\begin{array}{l}F_{1,75}=42.20 \\
P<0.001\end{array}$ & $\begin{array}{l}F_{1,75}=0.01 \\
P=0.97\end{array}$ & $\begin{array}{l}F_{1,75}=0.04 \\
P=0.84\end{array}$ \\
\hline GABARAP & $\begin{array}{l}F_{1,75}=83.76 \\
P<0.001\end{array}$ & $\begin{array}{l}F_{1,75}=2.64 \\
P=0.11\end{array}$ & $\begin{array}{l}F_{1,75}=3.31 \\
P=0.07\end{array}$ \\
\hline GRa & $\begin{array}{l}F_{1,75}=7.69 \\
P=0.007\end{array}$ & $\begin{array}{l}F_{1,75}=0.89 \\
P=0.35\end{array}$ & $\begin{array}{l}F_{1,75}=2.27 \\
P=0.14\end{array}$ \\
\hline GRß & $\begin{array}{l}F_{1,75}=9.74 \\
P=0.003\end{array}$ & $\begin{array}{l}F_{1,75}=0.15 \\
P=0.90\end{array}$ & $\begin{array}{l}F_{1,75}=0.62 \\
P=0.43\end{array}$ \\
\hline GRY & $\begin{array}{l}F_{1,75}=14.50 \\
P<0.001\end{array}$ & $\begin{array}{l}F_{1,75}=0.13 \\
P=0.72\end{array}$ & $\begin{array}{l}F_{1,75}=4.00 \\
P=0.049\end{array}$ \\
\hline GSR & $\begin{array}{l}F_{1,75}=14.171 \\
P<0.001\end{array}$ & $\begin{array}{l}F_{1,75}=0.34 \\
P=0.56\end{array}$ & $\begin{array}{l}F_{1,75}=0.86 \\
P=0.36\end{array}$ \\
\hline $\mathrm{MHC1}$ & $\begin{array}{l}F_{1,75}=10.6 \\
P=0.002\end{array}$ & $\begin{array}{l}F_{1,75}=0.001 \\
P=0.98\end{array}$ & $\begin{array}{l}F_{1,75}=1.18 \\
P=0.28\end{array}$ \\
\hline MR & $\begin{array}{l}F_{1,75}=34.86 \\
P<0.001\end{array}$ & $\begin{array}{l}F_{1,75}=1.62 \\
P=0.21\end{array}$ & $\begin{array}{l}F_{1,75}=0.18 \\
P=0.67\end{array}$ \\
\hline RBP1 & $\begin{array}{l}F_{1,75}=3.21 \\
P=0.08\end{array}$ & $\begin{array}{l}F_{1,75}=5.69 \\
P=0.02\end{array}$ & $\begin{array}{l}F_{1,75}=0.03 \\
P=0.86\end{array}$ \\
\hline
\end{tabular}

reflect temperature-induced physiological processes $[1$, $3]$. Gene expression of EPD1, one of the many genes we studied with higher mRNA levels at 3 than at $8{ }^{\circ} \mathrm{C}$, increases when fish experience environmental stress [56, 57]. Moreover, EPD1 activation in common carp (Cyprinus carpio) and zebrafish (Danio rerio) is strongly associated with cold acclimation, where increased EPD1 mRNA levels at reduced temperatures are stable until the temperature changes [56]. These findings are consistent with our observation of brown trout EPD1 mRNA levels. Hence, our results lend support to the notion that thermal effects on processes related to physiological stress and immune function in poikilotherms can play a major role [56]. Thus, the present study suggests

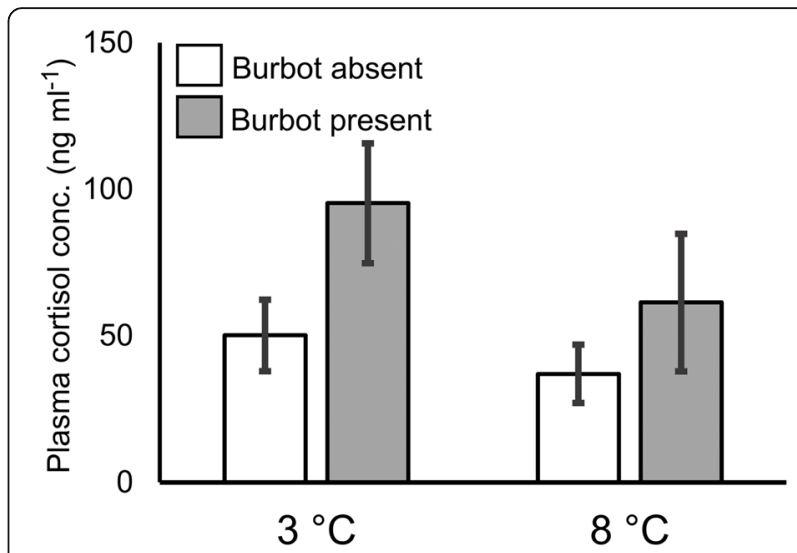

Fig. 2 Mean plasma cortisol concentrations in juvenile brown trout (Salmo trutta) ( $N=80$, see Table 3 ) at 3 and $8{ }^{\circ} \mathrm{C}$ in the presence and absence of predatory burbot (Lota lota). Two-way ANOVA revealed that the presence of burbot had a significant effect on trout plasma cortisol levels $(P<0.01)$, regardless of temperature treatment. Error bars denote \pm 1 s.e

that elevated winter temperatures result in reduced expression of stress-related genes in juvenile brown trout, with possible benefits for the fish if low winter temperatures induce chronic physiological stress [53, 54]. Indirect effects of mild winters should not be omitted however, for instance if high winter temperatures lead to loss of surface ice cover, possibly making stream fishes more susceptible to terrestrial predators.

Even though trout exhibited elevated plasma cortisol levels in the presence of a burbot, mRNA levels of genes that code for CRF and cortisol receptors (CRF1, CRFR1, CRHBP, GR $\alpha, G R \beta, G R \gamma$ and MR) did not differ between treatments with and without the predator. One possible explanation for this result could be that the expressions of these genes normally occur over a different time interval than the one tested in this study. In sockeye salmon $(O$. nerka), increased CRF mRNA expression occurs $8 \mathrm{~h}$ after acute stress [70], and in zebrafish, upregulation of MR after an acute stressor occurs after $24 \mathrm{~h}$ [71]. Hence, the possibility that mRNA expression and increased cortisol levels do not occur simultaneously could explain why cortisol levels differed significantly between predator treatments in our study, whereas no effects were detected for mRNA levels of CRF or other cortisol-related genes. In contrast, in a study where rainbow trout were subjected to a simulated attack from an avian predator, fish had elevated CRF mRNA levels after the attack, but did not exhibit increased plasma cortisol levels [62]. Studies that consider wider time spans, as well as differences in gene expression depending on what kind of stressor fish experience, may be necessary to clarify these mechanisms.

RBP1 mRNA levels were higher in the presence of burbot than in its absence. RBP1 is involved in the 


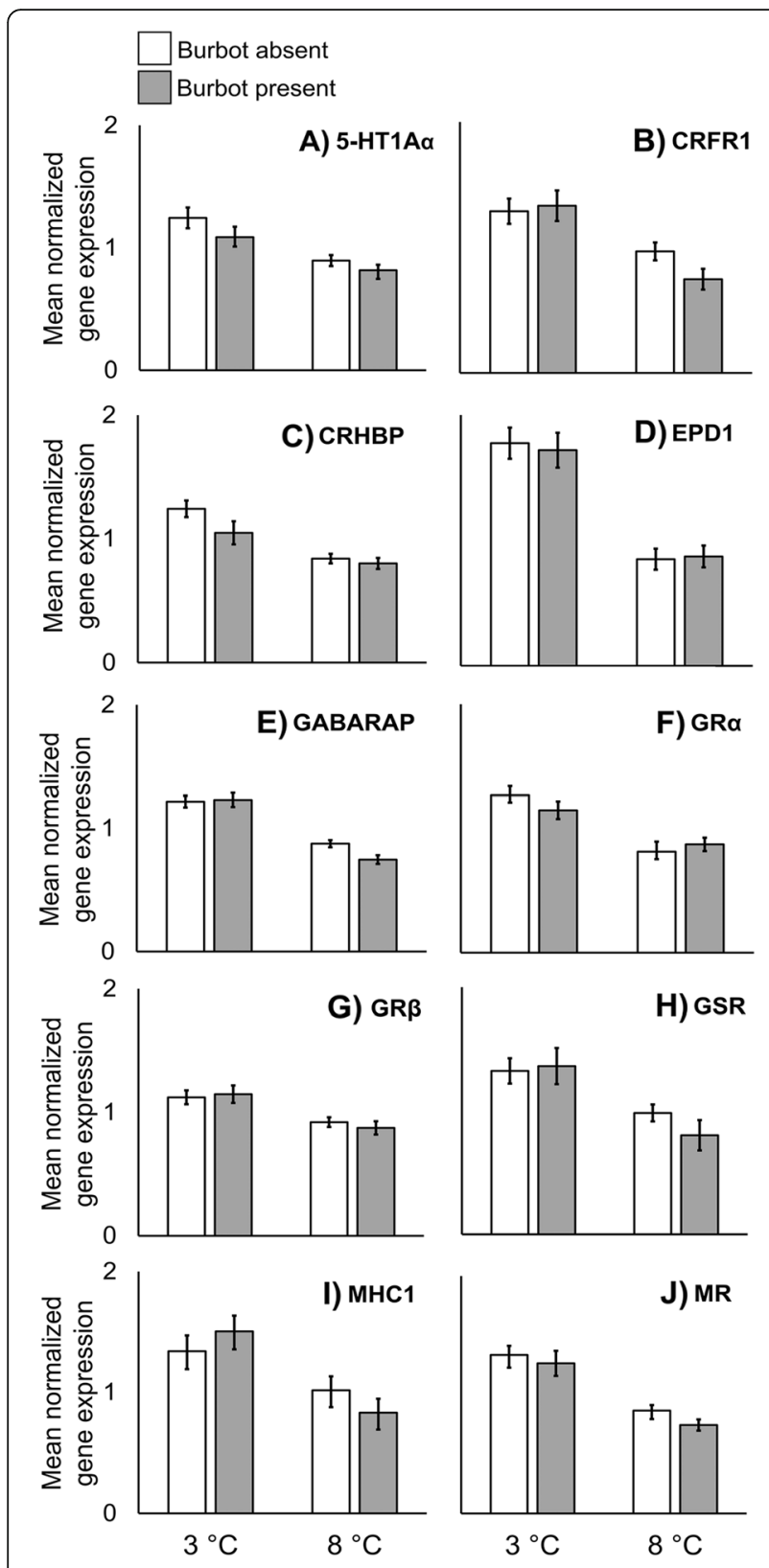

Fig. 3 Mean telencephalic gene expressions, measured as relative mRNA levels, of 5-HT1Aa, CRFR1, CRHBP, EPD1, GABARAP, GRa, GRB, GSR, MHC1 and MR in juvenile brown trout (Salmo trutta) $(\mathrm{N}=79$, see Table 3$)$ at 3 and $8^{\circ} \mathrm{C}$ in the presence and absence of predatory burbot (Lota lota). Only plots in which there were significant temperature effects $(P<0.01)$ in twoway ANOVAs are shown. Error bars denote \pm 1 s.e

distribution of retinol (vitamin A), which in the form of retinoic acid affects neural plasticity [59]. In zebrafish, physiological stress affects processes related to neural plasticity [72], with subsequent effects on behaviour [30]. High levels of RBP1 mRNA in the presence of a predator may be related to neuroendocrine regulation and altered behaviour. CALM is also associated with neural plasticity and may be affected by stress $[59,61]$.
In our study however, temperature and predator presence did not influence brain gene expression of CALM. As the functions of both RBP1 and CALM in modulating fish behaviour are not well understood, further studies are needed to elucidate how these processes are involved in anti-predator responses.

Aggression and dominance are often associated with boldness and risk-taking behaviours [73]. In salmonids, GABARAP and EPD1 are involved in both aggression [55, 58] and anti-predator responses [62]. 5-HT and AVT are also related to aggression and dominance in fish [42, 51, 74], and the role of 5-HT in the inhibitory control of aggressive and dominant behaviours seems to be evolutionarily conserved in many animal taxa [7577]. In our study, 5 -HT1A $\beta$ mRNA levels were significantly lower in the presence than in the absence of a burbot at $8{ }^{\circ} \mathrm{C}$, but not at $3{ }^{\circ} \mathrm{C}$. As we were not able to correlate behaviour with gene expressions in this study, however, we cannot infer that the variation in $5-\mathrm{HT} 1 \mathrm{~A} \beta$ expression is reflected in trout behaviour. In fact, the results from Filipsson et al. (2019) [12], a study with similar temperature and predator treatments as in this study, did not find temperature-dependent behavioural responses of trout to the presence of burbot.

We used three primer pairs for glucocorticoid receptors, although there is evidence for only two types of glucocorticoid receptors in teleosts (GR1 and GR2) [78, 79]. We did so as none of the previous studies from which we retrieved the primer sequences examined gene expression for brown trout. Instead, they used the closely related Atlantic salmon (S. salar) (GR $\alpha$ in the present study) [61] and rainbow trout (GR $\beta$ and GR $\gamma$ in the present study) [40], and since we had no way of knowing the relevant primers, we elected to run all three. All GR-genes showed major differences in mRNA levels between temperature treatments, as did many other genes in this study. The analysis of GR $\gamma$ also exhibited a significant interaction effect between temperature and predator presence, although with a $P$ value close to alpha $(P=0.049)$. Considering the interaction effects were non-significant for the analyses of GR $\alpha$ and GR $\beta$, we believe that the interaction effect found for GRY should be interpreted with caution.

\section{Conclusions}

Our study provides new insight into the regulation of plasma cortisol levels and brain gene expression in juvenile brown trout at different temperatures in the presence of a winter-active predatory fish. Our results demonstrate that elevated temperatures can potentially have broad effects on physiological stress responses in fish. We also show that both thermal effects and antipredator responses are detectable at the gene expression level. Future studies on both long- and short-term 


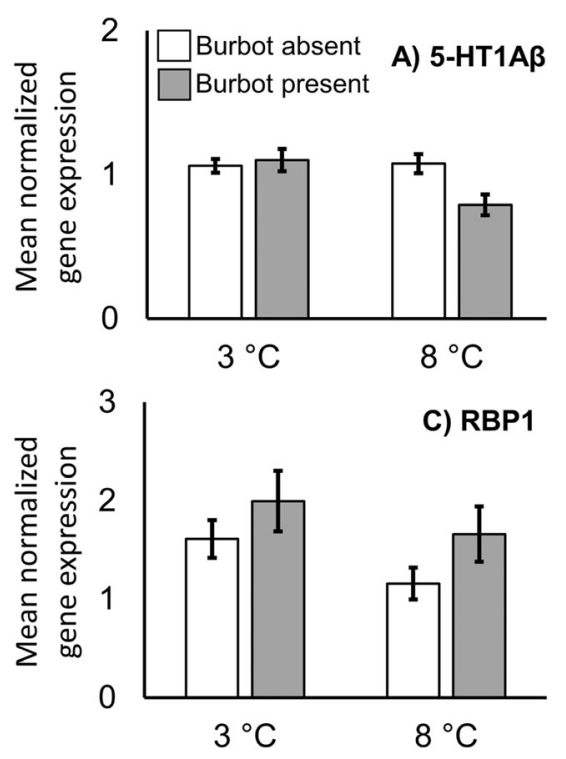

Fig. 4 Mean telencephalic gene expressions, measured as relative mRNA levels, of 5-HT1Aß, GRy and RBP1 in juvenile brown trout (Salmo trutta) $(N=79$, see Table 3) at 3 and $8{ }^{\circ} \mathrm{C}$ in the presence and absence of predatory burbot (Lota lota). Only plots in which there were significant predator or temperature $\times$ predator effects $(P<0.05)$ in two-way ANOVAs are shown. Error bars denote \pm 1 s.e

temperature effects on behaviour and gene expression, for instance in light of ongoing climate change, are needed to elucidate how stress responses may be affected in an altered climate. Gene expression encompasses more than mRNA levels, as it includes the array of processes that transfer information from gene to functional protein. It may be a fruitful approach to include analyses of gene end products (i.e. proteins) to determine the biological significance of changes in mRNA levels. Hence, studies of relationships between mRNA levels, protein levels and functions and behaviour can be valuable when evaluating potential effects of climate change.

\section{Methods}

\section{Study fish and husbandry}

We retrieved 120 one-summer-old $F_{1}$ hatchery-reared brown trout originating from the River Rottnan, Sweden, from Gammelkroppa hatchery (Gammelkroppa Lax AB) in late January 2018, and transported them to Karlstad University, Sweden. Trout mean wet mass \pm 1 s.d. was $8.26 \pm 2.3 \mathrm{~g},(\mathrm{~min}-\max =4.33-14.47 \mathrm{~g})$ and mean total length \pm 1 s.d. was $100 \pm 9 \mathrm{~mm}$, $(\min -\max =82-121$ $\mathrm{mm}$ ). Upon arrival, trout were acclimated from $1^{\circ} \mathrm{C}$ to $3{ }^{\circ} \mathrm{C}$ during a 48 -h period and evenly distributed into four $200 \mathrm{~L}$ aquaria with a water temperature of $3^{\circ} \mathrm{C}$. In two of the aquaria, we kept the temperature constant at $3{ }^{\circ} \mathrm{C}$. In the remaining two, we increased the temperature gradually to $8{ }^{\circ} \mathrm{C}$ during a two-week period $\left(+0.5^{\circ} \mathrm{C}\right.$ every weekday). Trout were allowed to acclimate to aquarium conditions for 3 weeks before the experiment commenced. The photoperiod was set to $10 \mathrm{~h}$ daylight (07:00-17:00 h) and 14 $\mathrm{h}$ darkness. Water in the aquaria was constantly filtered and aerated (EHEIM 2217 Classic canister filter; Eheim GmbH \& Co KG, Deizisau, Germany) and chilled (Teco TK 2000, Teco, Ravenna, Italy), and $25 \%$ of the water was changed every week. We fed trout thawed, previously frozen, red chironomids ( $0.5 \%$ of their body mass twice per week).

In the study, we used two burbot ( 360 and $375 \mathrm{~mm}$ ) captured in February 2018 at the mouth of the River Klarälven close to Lake Vänern, Sweden $\left(59^{\circ} 21.908^{\prime} \mathrm{N}\right.$ $\left.13^{\circ} 33.071^{\prime} \mathrm{E}\right)$ using fish traps. The burbot were transported to Karlstad University and acclimated from $1{ }^{\circ} \mathrm{C}$ to 3 and $8^{\circ} \mathrm{C}$, respectively, over a one-week period in net cages $(100 \times 50 \mathrm{~cm})$ inside two 7 -m-long stream flumes. Burbot were thereafter acclimated to aquarium conditions for 1 week before the experiment commenced. The same photoperiod was used as for the trout. We fed the burbot three thawed, previously frozen, brown trout (individual trout mass $\sim 5 \mathrm{~g}$ ) every week.

\section{Experimental procedure}

We conducted the experiment from mid-February to mid-April 2018. We used a $2 \times 2$ experimental design, testing the effects of temperature and predation risk: $3{ }^{\circ} \mathrm{C}$ with burbot, $3^{\circ} \mathrm{C}$ without burbot, $8^{\circ} \mathrm{C}$ with burbot, $8^{\circ} \mathrm{C}$ without burbot. Trout size did not differ significantly between treatments (one-way ANOVA, $P=0.995$ and $P=0.773$ for trout wet mass and total length, respectively). All trials were conducted in eight $130 \mathrm{~L}$ aquaria $(65 \times 50 \times 40 \mathrm{~cm})$. Water depth in the aquaria 
was $20 \mathrm{~cm}$ and the bottom substrate consisted of gravel $(5-20 \mathrm{~mm})$. We covered all four sides of each aquarium with black sheeting. In addition, a curtain shielded the aquaria from outside disturbance during the experiment. We used four aquaria in each trial, one for each experimental treatment. The aquaria we used for each trial were predetermined from a randomization protocol. In half of the aquaria, the water temperature was $3^{\circ} \mathrm{C}$ and in the remaining aquaria $8{ }^{\circ} \mathrm{C}$. Into each of the four aquaria, a transparent plastic chamber $(38 \times 27 \times 27 \mathrm{~cm})$ was inserted for holding the trout. The transparent chambers had $5 \mathrm{~mm}$ diameter holes on each end, ensuring that trout could both see and smell the burbot, but not interact physically. Thus, one trout was placed into each of the chambers, and one burbot was placed in two of the aquaria (one at $3{ }^{\circ} \mathrm{C}$ and one at $8{ }^{\circ} \mathrm{C}$ ), outside of the plastic chambers. In preparation for an experimental trial, we randomly selected trout from their respective holding aquaria $\left(3\right.$ and $8^{\circ} \mathrm{C}$ ), and thereafter anaesthetized them with tricaine methanesulfonate (MS-222, Pharmac Ltd., UK, $0.25 \mathrm{~g} \mathrm{~L}^{-1}$ ) and measured their total length $(\mathrm{mm})$ and mass $(0.01 \mathrm{~g})$. Each trout was placed in an experimental aquarium containing water corresponding to the trout's acclimation temperature.

At $\sim 18: 00 \mathrm{~h}$, we placed the trout in the experimental aquaria and left them overnight (with the same light regime as previously described). We subjected trout to the experiment for $20 \mathrm{~h}$, to ensure that the measured physiological stress response not was an artefact of handling the fish or the novel environment to which we introduced trout. Further, burbot is a nocturnal species, so leaving trout with burbot overnight suggests that trout were subjected to the predator under the light conditions when it usually is active [80]. After $\sim 20 \mathrm{~h}$, we hand-netted the trout and placed them in a lethal dose $\left(1.5 \mathrm{~g} \mathrm{~L}^{-1}\right)$ of tricaine methanesulfonate (MS-222, Pharmac Ltd., UK). Trout were euthanized at the same time every day (14: $00 \pm 1 \mathrm{~h}$ ) to control for potential diel variation in plasma cortisol and mRNA levels [81]. Trout exhibited loss of equilibrium after $<30 \mathrm{~s}$ and ceased opercular ventilation after $<60 \mathrm{~s}$. When no opercular beats could be observed for $10 \mathrm{~s}$ and when trout did not respond to strong tactile stimuli, they were euthanized by decapitation and exsanguination. We immediately drew blood samples from the caudal vein by tail ablation, using $75 \mu \mathrm{l}$ heparinized hematocrit tubes, which were centrifuged for $3 \mathrm{~min}$ at 1500 rpm (Hettich D-7200, Hettich GmbH \& Co, Tuttlingen, Germany). After centrifugation, blood plasma was isolated and immediately frozen at $-20^{\circ} \mathrm{C}$. Following the blood sampling, we dissected the telencephalon, placed it in $5 \mathrm{ml}$ RLT Plus Buffer (Qiagen, Hilden, Germany) with 2-mercaptoethanol (Sigma-Aldrich, Stockholm, Sweden) and homogenized the tissue using a tissue disruptor with disposable probes (TissueRuptor II, Qiagen, Hilden,
Germany). We thereafter extracted RNA using RNeasy plus mini kits (Qiagen, Hilden, Germany), in accordance with the supplier's manual, eluted in $30 \mu \mathrm{l}$ water and stored at $-20^{\circ} \mathrm{C}$ until use.

\section{Cortisol measurements}

Plasma cortisol concentrations were measured using a competitive enzyme-linked immunosorbent assay (detection range $0-1000 \mathrm{ng} \mathrm{ml}^{-1}$; EKU03476, Cortisol (Cor) ELISA kit, Biomatik, Ontario, Canada), carried out in accordance with the supplier's manual. We performed a negative control for unspecific degradation of substrate by endogenous plasma peroxidase for each sample.

\section{Gene expression measurements}

We assessed the concentration and quality of RNA in each sample with spectrophotometry (Tecan infinite M200 PRO, Tecan trading AG, Männedorf, Switzerland). We synthesized cDNA using $\mathrm{RT}^{2}$ First Strand Kits (Qiagen, Hilden, Germany), adding 500 ng extracted RNA. We diluted the cDNA 1:10 and stored it at $-20^{\circ} \mathrm{C}$. For the gene expression analysis, we selected 16 target genes related to physiological stress responses (including cortisol, serotonin, vasotocin and immune function genes) (Table 2). Primer sequences were obtained from previously published studies $[40,61,63]$ and were synthesized by Invitrogen (ThermoFisher Scientific, USA). We performed Quantitative Real-Time PCR (qPCR) with a StepOnePlus Real-Time PCR System (Applied Biosystems, ThermoFisher Scientific, USA), using $\mathrm{RT}^{2}$ SYBR Green ROX qPCR Mastermix (Qiagen, Hilden, Germany) in accordance with instructions from the manufacturer's protocol. The qPCR reactions were performed in a total volume of $12.5 \mu \mathrm{l}$ with $4 \mu \mathrm{l} \mathrm{cDNA}$ diluted $1: 10$ and $200 \mathrm{nM}$ of forward and reverse primers. We analysed samples in duplicates and included negative controls. The qPCR protocol consisted of initial denaturation at $95^{\circ} \mathrm{C}$ for $10 \mathrm{~min}$, followed by a two-step cycling protocol $\left(95^{\circ} \mathrm{C}\right.$ for $15 \mathrm{~s}+$ $60^{\circ} \mathrm{C}$ for $60 \mathrm{~s}$ ) for 40 cycles. Melting curve analyses determined the identity and specificity of the PCR products. Cycle threshold was recorded for each sample, and target mRNA levels were normalized, using $\beta$-actin and elongation factor $1 \alpha(E F 1 \alpha)$ as reference genes (Table 2). Fold changes were calculated using the $2^{-\Delta \Delta C T}$ method [82].

\section{Statistical analyses}

Our original design was balanced with equal numbers of replicates of the four experimental treatments. Initially, we used four burbot in this study. Two burbot did however exhibit strong symptoms of stress and deteriorating health during the experiment. To ensure the well-being of these animals, we removed them from the experiment and consequently excluded all cortisol and gene expression data generated from trials with these burbot. 
Table 2 Genes, accession numbers and primer sequences used for qPCR analysis. Asterisks denote reference genes

\begin{tabular}{llll}
\hline Gene & Accession No. & Forward primer & Reverse primer \\
\hline 5-HT1Aa & AGKD01067361 & ATGCTGGTCCTCTACGGGCG & CGTGGTTCACCGCGCCGTTT \\
5-HT1Aß & DY694524 & TTGATCATGCGTTCCCAGCCGA & AAAGGAATGTAGAACGCGCCGA \\
CALM & AGKD01053513 & ACGGGTTCATCTGCCACAGCA & TGACAGTTCTCAATTTCGCTCTGGA \\
CRF1 & BT057678 & TGCTGCAGAGCTGCGTCACG & AGCCTCCCGGATCATCTCATCCA \\
CRFR1 & NM_001141590 & CACACCCACATCCTAGGCTACTCAA & TAGCGGGGTTGGAAGGCACCA \\
CRHBP & AKD01020666 & ATCCAGAAGAAGTTTGTCAC \\
EPD1 & AM_001173799 & TTGAGAAGCGTTGGAACCTGAT & AGCTGCTCTCGGAAAGTCCCCT \\
GABARAP & NM_001140909 & TTGGTTGGTTGGTTGGGGCTG \\
GRa & NM_001142717 & ATCTGTGAGGGTGTGGAGCTGGAG & CCGCTGTCGGCGACCCG \\
GRß & GQ179974 & ACTCCCCCTCCTTCCCTCATCCA & ATGGCTTTGAGCAGGGATAG \\
GRY & NM_001124730.1 & TGGCCTGTATCCCCCACTGCC & CTCCCTGTCTCCCTCTGTCA \\
GSR & NM_001124482.1 & ACGACGATGGAGCCGAAC & CCGGCCCCCACTATGAC \\
MHC1 & BG934480 & TGGTGGGCTGCTGGATTTCTGC & CTGTCGCGTGGCAGGTCACT \\
MR & AF504021 & CCAGTGATGGCTTTTTTGAACTT & TCAGGGTGATTTGGTCCTCTATGG \\
RBP1 & AGKD01011423 & AATGGATCGCCCCAACGCCA & TCCTGTGCCCAGCATGTCGC \\
B-actin* & NM_001140773.2 & AGCTGGCTGGGAAACAGATGA & AGGGACAACACTGCCTGGAT \\
EF1a* & BG933897 & GTGGCGGGGCCTACGCTAT & AGTTACCAGCAGCTTTCTTCC
\end{tabular}

5-HT1Aa serotonin 1a-like receptor; 5-HT1Aß serotonin 1b-like receptor; AVTR arginine-vasotocin receptor; CALM calmodulin; CRF1 corticotropin-releasing factor 1; CRFR1 corticotropin-releasing factor receptor 1; CRHBP corticotropin-releasing factor binding protein; EPD1 ependymin; GABARAP gamma-aminobutyric acid receptor-associated protein; GRa glucocorticoid receptor; GRß glucocorticoid receptor 1; GRY glucocorticoid receptor 2; GSR glutathione reductase; MHC1 major histocompatibility complex $1 ; M R$ mineralocorticoid receptor; RBP1 retinol binding protein $1 ; \beta$-actin $\beta$-actin; EF1a elongation factor $1 a$

Inadequate blood sampling of four trout and low RNA

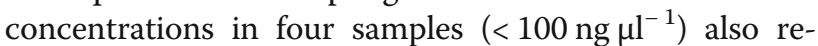
duced the sample size. Hence, replicates in each experimental treatment varied between 9 and 28 (Table 3).

We used a multivariate approach to explore the data. A detrended correspondence analysis indicated axis gradient lengths of $<1$, suggesting that a linear method was appropriate. We conducted a variance-partitioned redundancy analysis (RDA), using temperature and predator treatments as explanatory factors, to determine how much of the observed variation that could be explained by the experimental treatments. Multivariate analyses were performed in Canoco 5 (Microcomputer Power, Ithaca, NY, USA). To examine effects on cortisol and individual gene expressions, we subsequently analysed the data using two-way ANOVAs. Cortisol and gene expression data were first tested for normality and homogeneity of variances using the Kolmogorov-Smirnov test and Levene's test for equality of variances. Data that did not

Table 3 The number of juvenile brown trout used to generate the data presented in this study (i.e. final sample size)

\begin{tabular}{llllll}
\hline & \multicolumn{2}{l}{ Cortisol } & & & mRNA \\
\cline { 2 - 3 } \cline { 5 - 6 } & Burbot present & Burbot absent & & Burbot present & Burbot absent \\
\hline $3^{\circ} \mathrm{C}$ & 15 & 28 & 15 & 27 \\
$8^{\circ} \mathrm{C}$ & 9 & 28 & 9 & 28 \\
\hline
\end{tabular}

meet these assumptions (Cortisol, CALM, 5-HT1A $\alpha$, CRF1, CRFR1, GABARAP and MR) were $\log _{10}$-transformed. All models used temperature $\left(3\right.$ and $\left.8^{\circ} \mathrm{C}\right)$ and predator treatment (burbot presence and absence) as fixed factors, including the interaction term. All univariate analyses were conducted in IBM SPSS Statistics 24 (IBM, Armonk, NY, USA).

\section{Acknowledgements}

We are grateful to Johnny Norrgård, Gammelkroppa Lax AB and Fortum Generation AB for providing brown trout, and to the County Board in Värmland for giving us permission to collect burbot (Registration No. S2410). We also want to thank Niclas Carlsson for help in the field and Geni Zanol for preparing chemical solutions.

\section{Authors' contributions}

KF had the leading role in the study design, conducted fieldwork and wrote the initial version of the manuscript. EB, AE, LG, MÖ and JW all contributed to the research idea and study design and made considerable improvements to the manuscript. KF and AE conducted laboratory work, both aquarium experiments and cortisol and gene expression measurements. KF and JW analysed the data. All authors read and approved the final manuscript.

\section{Funding}

Open access funding provided by Karlstad University.

\section{Availability of data and materials}

The datasets used and analysed during the current study are available from the corresponding author on request.

Ethics approval and consent to participate

All applicable international, national and institutional guidelines for the care and use of animals were followed. All procedures performed involving 
animals were in accordance with the ethical standards of the institution at which the study was conducted. This study was approved by the Swedish Ethical Committee on Animal Experiments (reference 85-2013 for the fish collection and reference 88-2013 for the laboratory experiments).

\section{Consent for publication}

Not applicable.

\section{Competing interests}

The authors declare that they have no competing interests.

\section{Received: 10 June 2020 Accepted: 20 August 2020}

Published online: 28 August 2020

\section{References}

1. Dell Al, Pawar S, Savage VM. Systematic variation in the temperature dependence of physiological and ecological traits. PNAS. 2011;108:10591-6.

2. Dell Al, Pawar S, Savage VM. Temperature dependence of trophic interactions are driven by asymmetry of species responses and foraging strategy. J Anim Ecol. 2014;83:70-84.

3. Englund $G$, Öhlund $G$, Hein $C L$, Diehl S. Temperature dependence of the functional response. Ecol Lett. 2011;14:914-21.

4. Grigaltchik VS, Ward AJW, Seebacher F. Thermal acclimation of interactions: differential responses to temperature change alter predator-prey relationship. P Roy Soc B. 2012;279:4058-64.

5. Öhlund G, Hedström P, Norman S, Hein CL, Englund G. Temperature dependence of predation depends on the relative performance of predators and prey. P Roy Soc B. 2014;282:20142254

6. Greenberg L. Effects of predation and discharge on habitat use by brown trout, Salmo trutta, and grayling, Thymallus thymallus, in artificial streams. Arch Hydrobiol. 1999;145:433-46.

7. Hirvonen H, Ranta E, Piironen J, Laurila A, Peuhkuri N. Behavioural responses of naive Arctic charr young to chemical cues from salmonid and nonsalmonid fish. Oikos. 2000;88:191-9.

8. Mirza RS, Chivers DP. Behavioural responses to conspecific disturbance chemicals enhance survival of juvenile brook charr, Salvelinus fontinalis, during encounters with predators. Behav. 2002;139:1099-109.

9. Vilhunen $\mathrm{S}$, Hirvonen $\mathrm{H}$. Innate antipredator responses of Arctic charr (Salvelinus alpinus) depend on predator species and their diet. Behav Ecol Sociobiol. 2003;55:1-10.

10. Hawkins LA, Armstrong JD, Magurran AE. Predator-induced hyperventilation in wild and hatchery Atlantic salmon fry. J Fish Biol. 2004;65:88-100.

11. Enefalk $\AA$, Watz J, Greenberg L, Bergman E. Winter sheltering by juvenile brown trout (Salmo trutta) - effects of stream wood and an instream ectothermic predator. Freshw Biol. 2017;62:111-8.

12. Filipsson K, Bergman E, Österling M, Erlandsson A, Greenberg L, Watz J. Effects of temperature and a piscivorous fish on diel winter behaviour of juvenile brown trout (Salmo trutta). Freshw Biol. 2019:64:1797-805.

13. Weetman D, Atkinson D, Chubb JC. Effects of temperature on anti-predator behaviour in the guppy, Poecilia reticulata. Anim Behav. 1998;55:1361-72.

14. Weetman $D$, Atkinson $D$, Chubb JC. Water temperature influences the shoaling decisions of guppies, Poecilia reticulata, under predation threat. Anim Behav. 1999:58:735-41.

15. Malavasi S, Cipolato G, Cioni C, Torricelli P, Alleva E, Manciocco A, Toni M. Effects of temperature on the antipredator behaviour and on cholinergic expression in the European sea bass (Dicentrarchus labrax L.) juveniles. Ethology. 2013;119:592-604.

16. Lienart GDH, Mitchell MD, Ferrari MCO, McCormick MI. Temperature and food availability affect risk assessment in an ectotherm. Anim Behav. 2014; 89:199-204.

17. Pink M, Abrahams MV. Temperature and its impact on predation risk within aquatic ecosystems. Can J Fish Aquat Sci. 2016;73:869-76.

18. Brown RD. Northern hemisphere snow cover variability and change, 191597. J Clim. 2000;13:2339-55.

19. Magnuson JJ, Robertson DM, Benson BJ, Wynne RH, Livingstone DM, Arai T, Assel RA, Barry RG, Card V, Kuusisto E, et al. Historical trends in lake and river ice cover in the northern hemisphere. Science. 2000;289:1743-6.

20. Parmesan C. Ecological and evolutionary responses to recent climate change. Annu Rev Ecol Evol Syst. 2006;37:637-69.

21. Post E, Forchhammer MC, Bret-Harte MS, Callaghan TV, Christensen TR, Elberling B, Fox AD, Gilg O, Hik DS, Høye TT, et al. Ecological dynamics across the Arctic associated with recent climate change. Science. 2009;325: 1355-8.

22. Choi G, Robinson DA, Kang S. Changing northern hemisphere snow seasons. J Clim. 2010;23:5305-10.

23. Callaghan TV, Johansson M, Brown RD, Groisman PY, Labba N, Radionov V, Barry RG, Bulygina ON, Essery RLH, Frolov DM, et al. The changing face of Arctic snow cover: a synthesis of observed and projected changes. Ambio. 2011:40:17-31.

24. Barton BA. Stress in fishes: a diversity of responses with particular reference to changes in circulating corticosteroids. Integr Comp Biol. 2002:42:517-25.

25. Johansen IB, Sandvik GK, Nilsson GE, Bakken M, Øverli Ø. Cortisol receptor expression differs in the brains of rainbow trout selected for divergent cortisol response. Comp Biochem Phys D. 2011;6:126-32.

26. Wendelaar Bonga SE. The stress response in fish. Physiol Rev. 1997;77:591-625.

27. Mommsen TP, Vijayan MM, Moon TW. Cortisol in teleosts: dynamics, mechanisms of action, and metabolic regulation. Rev Fish Biol Fisher. 1999; 9:211-68.

28. Oitz MS, van Haarst AD, de Kloet ER. Behavioral and neuroendocrine responses controlled by the concerted action of central mineralocorticoid (MRS) and glucocorticoid receptors (GRS). Psychoneuroendocrinology. 1997; 22:87-93.

29. Schjolden J, Basic D, Winberg S. Aggression in rainbow trout is inhibited by both MR and GR antagonists. Physiol Behav. 2009:98:625-30.

30. Sørensen C, Johansen IB, Øverli $\varnothing$. Neural plasticity and stress coping in teleost fishes. Gen Comp Endocrinol. 2013;181:25-34.

31. Rehnberg BG, Schreck CB. Chemosensory detection of predators by coho salmon (Oncorhynchus kisutch): behavioural reaction and the physiological stress response. Can J Zool. 1987:65:481-5.

32. Kagawa N, Mugiya Y. Brain HSP70 mRNA expression is linked with plasma cortisol levels in goldfish (Carassius auratus) exposed to a potential predator. Zool Sci. 2002;19:735-40.

33. Breves JP, Specker JL. Cortisol stress response of juvenile winter flounder (Pseudopleuronectes americanus, Walbaum) to predators. J Exp Mar Biol Ecol. 2005;325:1-7.

34. Barcellos LJG, Ritter F, Carlos L, Mezzalira R, Bolognesi L, Calliari A, Finco J, Cericato L. Whole-body cortisol increases after direct and visual contact with a predator in zebrafish, Danio rerio. Aquaculture. 2007:272:774-8.

35. Oliveira TA, Idalencio R, Kalichak F, dos Santos Rosa JG, Koakoski G, de Abreu MS, Giacomini ACV, Gusso D, Rosemberg DB, Barreto RE, et al. Stress responses to conspecific visual cues of predation risk in zebrafish. PeerJ. 2017. https://doi.org/10.7717/peerj.3739.

36. Archard GA, Earley RL, Hanninen AF, Braithwaite VA. Correlated behaviour and stress physiology in fish exposed to different levels of predation pressure. Funct Ecol. 2012;26:637-45.

37. Fischer EK, Harris RM, Hofmann HA, Hoke KL. Predator exposure alters stress physiology in guppies across timescales. Horm Behav. 2014;65:165-72.

38. Winberg S, Nilsson A, Hylland P, Söderström V, Nilsson GE. Serotonin as a regulator of hypothalamic-pituitary-interrenal activity in teleost fish. Neursci Lett. 1997;230:113-6.

39. Chaouloff F. Serotonin, stress and corticoids. J Psychopharmacol. 2000;14: 139-51.

40. Moltesen M, Laursen DC, Thörnqvist P-O, Åberg Andersson M, Winberg S, Höglund E. Effects of acute and chronic stress on telencephalic neurochemistry and gene expression in rainbow trout (Oncorhynchus mykiss). J Exp Biol. 2016;219:3907-14.

41. Schjolden J, Winberg S. Genetically determined variation in stress responsiveness in rainbow trout: behavior and neurobiology. Brain Behav Evolut. 2007;70:227-38

42. Winberg $\mathrm{S}$, Thörnqvist P-O. Role of brain serotonin in modulating fish behavior. Curr Zool. 2016;62:317-23.

43. Winberg S, Myrberg AA, Nilsson GE. Predator exposure alters brain serotonin metabolism in bicolour damselfish. Neuroreport. 1993;4:399-402.

44. Weinberger J, Klaper R. Environmental concentrations of the selective serotonin reuptake inhibitor fluoxetine impact specific behaviors involved in reproduction, feeding and predator avoidance in the fish Pimephales promelas (fathead minnow). Aquat Toxicol. 2014;151:77-83.

45. Khan NA, Deschaux P. Perspective role of serotonin in fish immunomodulation. J Exp Biol. 1997;200:1833-8.

46. Lyytikäinen T, Pylkkö P, Ritola O, Lindström-Seppä P. The effect of acute stress and temperature on plasma cortisol and ion concentrations and 
growth of Lake Inari Arctic charr, Salvelinus alpinus. Environ Biol Fishes. 2002; 64:195-202.

47. Davis KB. Temperature affects physiological stress responses to acute confinement in sunshine bass (Morone chrysops $\times$ Morone saxatilis). Comp Biochem Phys A. 2004;139:433-40.

48. Romero LM, Butler LK. Endocrinology of stress. Int J Comp Psychol. 2007;20: 85-95.

49. Semsar K, Kandel FLM, Godwin J. Manipulations of the AVT system shift social status and related courtship and aggressive behavior in the bluehead wrasse. Horm Behav. 2001:40:21-31.

50. Larson ET, Malley DMO, Melloni RH, Hall M, Ave H. Aggression and vasotocin are associated with dominant-subordinate relationships in zebrafish. Behav Brain Res. 2006;167:94-102.

51. Backström T, Winberg S. Arginine-vasotocin influence on aggressive behavior and dominance in rainbow trout. Physiol Behav. 2009;96:470-5.

52. Huffman LS, Hinz Fl, Wojcik S, Aubin-Horth N, Hofmann HA. Arginine vasotocin regulates social ascent in the African cichlid fish Astatotilapia burtoni. Gen Comp Endocrinol. 2015;212:106-13.

53. Tort L. Stress and immune modulation in fish. Dev Comp Immunol. 2011;35: 1366-75.

54. Engelsma MY, Huising MO, van Muiswinkel WB, Flik G, Kwang J, Savelkoul HFJ, Verburg-van Kemenade BML. Neuroendocrine-immune interactions in fish: a role for interleukin-1. Vet Immunol Immunop. 2002;87:467-79.

55. Sneddon LU, Schmidt R, Fang Y, Cossins AR. Molecular correlates of social dominance: a novel role for ependymin in aggression. PLoS One. 2011. https://doi.org/10.1371/journal.pone.0018181.

56. Tang S-J, Sun K-H, Sun G-H, Lin G, Lin W-W, Chuang M-J. Cold-induced ependymin expression in zebrafish and carp brain: implications for cold acclimation. FEBS Lett. 1999;459:95-9.

57. Smith RW, Cash P, Ellefsen S, Nilsson GE. Proteomic changes in the crucian carp brain during exposure to anoxia. Proteomics. 2009;9:2217-29.

58. de Almeida RMM, de Francesco P, Parmigiani S, Miczek KA. Escalated aggressive behavior: dopamine, serotonin and GABA. Eur J Pharmacol. 2005; 526:51-64.

59. Shearer KD, Stoney PN, Morgan PJ, McCaffery PJ. A vitamin for the brain Trends Neurosci. 2012;35:733-41.

60. Thomson JS, Watts PC, Pottinger TG, Sneddon LU. Physiological and genetic correlates of boldness: Characterising the mechanisms of behavioural variation in rainbow trout, Oncorhynchus mykiss. Horm Behav. 2011;59:67-74.

61. Thörnqvist P-O, Höglund E, Winberg S. Natural selection constrains personality and brain gene expression differences in Atlantic salmon (Salmo salar). J Exp Biol. 2015:218:1077-83.

62. Thomson JS, Watts PC, Pottinger TG, Sneddon LU. Plasticity of boldness in rainbow trout, Oncorhynchus mykiss: do hunger and predation influence risk-taking behaviour? Horm Behav. 2012;61:750-7.

63. Hansen BH, Rømma S, Garmo A, Olsvik PA, Andersen RA. Antioxidative stress proteins and their gene expression in brown trout (Salmo trutta) from three rivers with different heavy metal levels. Comp Biochem Phys C. 2006; 143:263-74

64. Wedemeyer GA, McLeay DJ. Methods for determining the tolerance of fishes to environmental stressors. In: Pickering AD, editor. Stress and fish New York: Academic Press; 1981. p. 247-75.

65. Wedemeyer GA, Barton BA, McLeay DJ. Stress and acclimation. In: Schreck CB, Moyle PB, editors. Methods for fish biology. Bethesda: American Fisheries Society; 1999. p. 451-89.

66. Metcalfe NB, Huntingford FA, Thorpe JE. The influence of predation risk on the feeding motivation and foraging strategy of juvenile Atlantic salmon. Anim Behav. 1987;35:901-11.

67. Lima SL, Dill LM. Behavioral decisions made under the risk of predation: a review and prospectus. Can J Zool. 1990;68:619-40.

68. Johnsson JI, Höjesjö J, Fleming IA. Behavioural and heart rate responses to predation risk in wild and domesticated Atlantic salmon. Can J Fish Aquat Sci. 2001;58:788-94.

69. Watz J. Stress responses of juvenile brown trout under winter conditions in a laboratory stream. Hydrobiologia. 2017;802:131-40.

70. Sopinka NM, Jeffrey JD, Burnett NJ, Patterson DA, Gilmour KM, Hinch SG. Maternal programming of offspring hypothalamic-pituitary-interrenal axis in wild sockeye salmon (Oncorhynchus nerka). Gen Comp Endocrinol. 2017;242: $30-7$
71. Alderman SL, Vijayan MM. 11b-Hydroxysteroid dehydrogenase type 2 in zebrafish brain: a functional role in hypothalamus-pituitary-interrenal axis regulation. J Endocrinol. 2012;215:393-402.

72. von Krogh K, Sørensen C, Nilsson GE, Øverli Ø. Forebrain cell proliferation, behavior, and physiology of zebrafish, Danio rerio, kept in enriched or barren environments. Physiol Behav. 2010;101:32-9.

73. Sih A, Bell A, Johnson JC. Behavioral syndromes: an ecological and evolutionary overview. Trends Ecol Evol. 2004;19:372-8.

74. Summers $\mathrm{CH}$, Winberg S. Interactions between the neural regulation of stress and aggression. J Exp Biol. 2006;209:4581-9.

75. Koolhaas JM, Korte SM, De Boer SF, Van Der Vegt BJ, Van Reenen CG, Hopster H, De Jong IC, Ruis MAW, Blokhuis HJ. Coping styles in animals: current status in behavior and stress-physiology. Neurosci Biobehav Rev. 1999;23:925-35

76. Lillesaar C. The serotonergic system in fish. J Chem Neuroanat. 2011:41:294-308.

77. Mahar I, Rodriguez F, Mechawar N, Nobrega JN. Stress, serotonin, and hippocampal neurogenesis in relation to depression and antidepressant effects. Neurosci Biobehav Rev. 2014;38:173-92.

78. Bury NR, Sturm A, Le Rouzic P, Lethimonier C, Ducouret B, Guiguen Y, Robinson-Rechavi M, Laudet V, Rafestin-Oblin ME, Prunet P. Evidence for two distinct functional glucocorticoid receptors in teleost fish. J Mol Endocrinol. 2003:1:141-56.

79. Stolte EH, Verburg-van Kemenade BML, Savelkoul HFJ, Flik G. Evolution of glucocorticoid receptors with different glucocorticoid sensitivity. J Endocrinol. 2006;190:17-28.

80. Hackney PA. Ecology of the burbot (Lota lota) with special reference to its role in the Lake Opeongo fish community. University of Toronto: PhD Thesis; 1973.

81. Pickering $A D$, Pottinger TG. Seasonal and diel changes in plasma cortisol levels of the brown trout, Salmo trutta L. Gen Comp Endocrinol. 1983;49: 232-9.

82. Livak KJ, Schmittgen TD. Analysis of relative gene expression data using realtime quantitative $P C R$ and the 2- $\Delta \Delta C T$ method. Methods. 2001:25:402-8.

\section{Publisher's Note}

Springer Nature remains neutral with regard to jurisdictional claims in published maps and institutional affiliations.
Ready to submit your research? Choose BMC and benefit from:

- fast, convenient online submission

- thorough peer review by experienced researchers in your field

- rapid publication on acceptance

- support for research data, including large and complex data types

- gold Open Access which fosters wider collaboration and increased citations

- maximum visibility for your research: over $100 \mathrm{M}$ website views per year

At $\mathrm{BMC}$, research is always in progress.

Learn more biomedcentral.com/submissions 